\title{
Technical communication pedagogical model (TCPM) for Malaysian vocational colleges
}

\author{
K. A. Jamaludin ${ }^{1}$, N. Alias ${ }^{1 凶}$, D. DeWitt ${ }^{1} \&$ M. M. Ibrahim²
}

Poor mastery of technical communication skills has affected the employability of technical and vocational education and training (TVET) graduates. This has arisen from the lack of communication between TVET institutions and the industry when designing a curriculum for technical communication skills development. In Malaysia, little emphasis is given to developing this skill. Therefore, the current study seeks to develop a technical communication pedagogical model (TCPM) by identifying the pertinent objective, content of learning, method of delivery and assessment method of TCPM, and the effect of the perceived importance of English language proficiency on the relationships of the pertinent curriculum components of TCPM. A survey questionnaire was developed and validated for content validation by seven experts from local industry and TVET institutions. A total of 205 English language instructors in Malaysian vocational colleges (MVC) were selected using a stratified random sampling method and responded to the questionnaire. Their responses were analyzed using the partial least square-structural equation modeling (PLS-SEM). Analysis of reliability, discriminant and convergent validity, significance of relationship, predictive accuracy $\left(R^{2}\right)$, predictive relevance $\left(Q^{2}\right)$, effect size $\left(f^{2}\right)$, and mediation analysis was conducted to test the model. The overall findings indicated that all constructs have a positive and significant effect on perceived importance of TCPM (Objective: $p=0.012, t=2.249$, content of learning: $p=0.032, t=1.852$, assessment method: $p=0.000, t=4.196)$, except for method of delivery $(p=0.301, t=0.522)$. The coefficient of determination level is moderate $\left(R^{2}=0.526\right)$. Analysis of effect size $\left(f^{2}\right)$ indicates a small effect size for all constructs (objective: $f^{2}=0.032$, content of learning: $f^{2}=0.027$, assessment method: $f^{2}=0.116$ ), except for method of delivery with an effect size of 0.002. In addition, this model achieved acceptable predictive relevance $\left(Q^{2}=0.316\right)$. On the other hand, the mediation analysis indicates that the perceived importance of English language proficiency only functions as a complementary partial mediator for content of learning and assessment method construct. In short, the TCPM model includes having the relevant objectives, content of learning, method of delivery and assessment method for implementing technical communication in MVC, components which are less emphasized in the current curriculum. It is hoped that, with its implementation in the MVC, graduate employability can be enhanced.

\footnotetext{
${ }^{1}$ Faculty of Education, University of Malaya, 50603 Kuala Lumpur, Malaysia. ${ }^{2}$ Faculty of Science and Mathematics, Universiti Pendidikan Sultan Idris, 35900 Tanjung Malim, Malaysia. ${ }^{凶}$ email: drnorlidah@um.edu.my
} 
Introduction

nemployment is a global issue. Countries, even the developed ones, are facing increasing unemployment rate due to the global shift of the current market from manufacturing to the service sector (Dobbs and Madgavkar, 2014). In their study, they predicted a potential shortage of 38-40 million high-skill workers and a surplus of 38-40 million low-skill workers, in the near future. In Malaysia, the unemployment issue is a unique case. Over the past few years, the unemployment rate has increased from $3.1 \%$ in 2015 to $3.4 \%$ in 2016 (Department of Statistics Malaysia, 2017) and has remained stagnant until 2018 (Department of Statistics Malaysia, 2018). However, until October 2019, the unemployment rate has dropped to 3.2\% (Department of Statistics Malaysia, 2019). A detailed analysis based on the available statistics until 2013 (in Table 1), revealed that the unemployment rate among graduates with tertiary education qualification has increased from $17.43 \%$ in 2010 to $25.81 \%$ in 2013.

Studies in the area of unemployment in Malaysia have appointed that poor mastery of employability skills, especially communication skills have affected employability of Malaysian graduates including graduates from tertiary education institutions (Hanapi and Nordin, 2014; Osman et al., 2015; Shuib, 2005).

In response to this growing demand for high-skill workers, technical vocational education and training (TVET) has become an important education platform to equip graduates with: (a) general education knowledge, (b) technical and scientific knowledge, (c) practical skills, positive attitudes and understanding of various working fields (The United Nations Educational, Scientific and Cultural Organization (UNESCO), 2011). In the recent Malaysia Education Blueprint 2013-2025, Ministry of Education Malaysia (2012) has highlighted the importance of TVET institutions in producing high-skill workers for the country. Vocational colleges, for example, focus on providing vocational training and academic education in order to achieve this aspiration. These institutions have been introduced to students as early as lower secondary levels (Yunos et al., 2006) with hopes to produce more knowledgeable and competent workers for the country (Hasmori et al., 2014; Ministry of Education Malaysia, 2012). Students may apply for junior vocational college for Malaysian Skills Certificate Level 1 and 2, and continue for their Diploma in either vocational colleges, public skills training institutions or private vocational colleges. Also, they are encouraged to further their studies in higher learning institutions for their degrees.

However, numerous studies have reported that TVET institutions are still struggling to equip graduates with strong communication-for-work skills (Mourshed et al., 2014; Nagendra et al., 2013; Oxtoby, 1997; Tabbron and Yang, 1997). A mismatch of expectation between industry and TVET institutions have also been reported in the literature (Mourshed et al., 2014; Oxtoby, 1997). Similarly, in Malaysia, Ibrahim et al. (2012) reported that the students in local TVET institutions were not well accepted by the industry. They believed that the curriculum in their institution was inadequate to prepare them for the industry. In fact, Nagendra et al. (2013) affirmed that there is no clear direction to guide the process of curriculum design and development, and assessment for communication-for-work skills.

Clearly, our TVET curriculum is still facing a challenge in producing high-skill workers, and thus, intensive improvements should be proposed and taken into consideration. In line with Minghat and Yasin's (2010) sustainable framework of Malaysian TVET, robust educational emphases should be given not only on content knowledge and technical skills but also on communication skills development. Even though communication skills have been proven to be lacking among students or graduates

\begin{tabular}{|c|c|c|c|c|}
\hline $\begin{array}{l}\text { Educational } \\
\text { attainment }\end{array}$ & $2010(\%)$ & $2011(\%)$ & (2012 (\%) & $2013(\%)$ \\
\hline Primary & 10.98 & 10.37 & 10.17 & 10.00 \\
\hline Secondary & 59.05 & 55.29 & 59.22 & 57.20 \\
\hline Tertiary & 17.43 & 25.64 & 22.71 & 25.81 \\
\hline No certificate & 5.59 & 4.42 & 4.39 & 3.72 \\
\hline
\end{tabular}

(Mourshed et al., 2014; Nagendra et al., 2013; Oxtoby, 1997; Tabbron and Yang, 1997), the current body of literature seems inadequate to mark the next step to improve communication skills in TVET institutions. Therefore, there is a need to develop a model for technical communication skills development in the Malaysian TVET institutions, especially the vocational colleges.

\section{Technical communication and the current TVET curriculum}

Numerous studies have suggested technical communication skills integration in TVET curriculum (Brinkman and van der Geest, 2003; Reaves, 2004; Rus, 2014). General communication courses offered in most institutions are viewed as inadequate to equip students with relevant communication-for-work skills (Brinkman and van der Geest, 2003; Kunioshi et al., 2012; Reaves, 2004; Rus, 2014). They believed that technical communication skills, such as interpersonal, verbal presentation, writing and researching skills, that are derived from communicative experiences in the real industry, are needed to be integrated into the TVET curriculum. However, the types of technical communication in the local industry should first be determined in ensuring the curriculum addresses the needs of the local industry.

In Malaysian Vocational Colleges, the current subjects such as General English (introduced in Semester 1 and 2 of Certificate level), English for specific purposes (ESP) (introduced in Semester 3 and 4 of Certificate level) and English for Communication (introduced to Diploma level) are majorly focusing on developing basic communication skills, and competency in English (Ministry of Education Malaysia, 2014a, 2014b, 2014c) and are not specifically designed to prepare them for communication in real industry. Therefore, there is a need to develop a technical communication pedagogical model (TCPM) for Malaysian vocational colleges. This will serve as a clear guideline for instructors to effectively implement the curriculum at micro-level (Batista et al., 2010).

\section{Classification of technical communication skills}

Mitchell (1962) firmly believes that technical communication is a strategic communication scheme across science and engineering fields, as well as industry. According to Mitchell (1962), technical communication consists of eight important elements: (1) content, (2) form, (3) audience level, (4) subject matter, (5) accepted usage and predictive arrangements, (6) conventions, (7) internal forms, and (8) scientific values and techniques. The content and form of technical communication must be suitable to the audience level to ensure information is effectively delivered to the audience. Also, a speaker must understand the subject matter and knows appropriate forms of communication and convention, either in oral or written form to effectively deliver the information and convince the target audience. In addition, in delivering information in working fields, an individual needs to master how to retrieve, structure, organize, and report work-related information in building a factual and convincing content of the communication. 
Technical communication can be categorized into two categories: oral presentation and social literacy skills. Oral presentation skills include the ability to: (1) retrieve relevant information from multiple sources related to a topic, (2) gather and organize information to ease understanding, (3) distinguish main ideas with supporting details, (4) plan introduction and conclusion for a presentation, (5) plan and develop the content of an oral presentation, (6) operate technological tools that can further help information gathering and communication, (7) acquire an awareness of technological tools to help promote social interactions and collaboration for work, and (8) plan and prepare visual aids to support the delivery of content (Brinkman and van der Geest, 2003; Cook, 2002; Lappalainen, 2010; McMurrey, 2002; Reaves, 2004; Rus, 2014).

On the other hand, social literacy skills include the ability to: (1) communicate effectively with co-workers and administrators, (2) effectively give instructions, (3) provide constructive feedbacks, (4) establish professional relationships with customers and co-workers, (5) share information in small group settings, (6) acquire multicultural awareness, (7) positively handle conflicts, (8) acquire leadership skills, and (9) produce business documents (Brinkman and van der Geest, 2003; Cook, 2002; Lappalainen, 2010; McMurrey, 2002; Reaves, 2004; Rus, 2014).

On the other hand, technical communication considers the development of English language proficiency skills. In general, technical communication shares characteristics of ESP which include prioritizing students' specific needs of communication and designing content that help to realize these needs. Also, English language proficiency is not the main focus but is embedded throughout the learning process (Strevens, 1988). Among important language skills relevant to technical communication are the ability to: (1) construct accurate sentence structures, (2) apply verbal communication strategy, and (3) comprehend information in a text. These skills are among important language skills for work, as highlighted in the Test of English for International Communication (Yoo and Manna, 2015) and Occupational English Test (Occupational English Test, 2016).

\section{Curriculum development}

Curriculum for TVET is viewed as an objective-driven curriculum. According to Ross (2000), vocational curriculum focuses on addressing social needs through education. This curriculum considers industry needs in designing its objective, content, method of delivery and assessment method. Wellington (1993) termed this as industry-based curriculum. The curriculum should, have: (1) established targets and programmes relevant to National Curriculum and field of work, (2) clear framework for knowledge and skills development of work and career development, (3) focus on personal and social skills development, and (4) include work-related activities.

As one of the widely practised curriculum models, Tyler's (1949) curriculum planning model is the basis for this pedagogical development as it is objective-driven. Tyler (1949) emphasizes on four important processes, which starts with establishing objectives and are followed by selecting learning experiences, organizing them and lastly, evaluation.

For this study, the proposed objectives are aligned with the characteristics of an industry-based curriculum and skills needed for technical communication skills development such as to: (1) develop oral, researching, interpersonal, and written technical communication skills, (2) provide and expose students to work-related communicative experiences, and (3) serve as a reference for effective implementation in Malaysian Vocational colleges.
Based on the review of literature, relevant methods of delivery include practical tutorials, collaborative learning activities, field training, a communication module, integration of technical communication across technical subjects, and contextualized learning activities (Lappalainen, 2010; Reaves, 2004).

On the other hand, the review of the literature suggests oral presentations, writing technical documents tasks, observations on students' communicative experiences during fieldworks and group activities, and evaluation of students' responses on the online forum as relevant assessment methods for technical communication development (Brinkman and van der Geest, 2003; McMurrey, 2002; Rus, 2014).

\section{The current study}

In introducing technical communication in Malaysian vocational colleges, this study is aimed at developing TCPM for the Malaysian vocational colleges as a reference for implementation. Therefore, this study seeks to achieve these objectives:

1. propose TCPM for the Malaysian vocational colleges,

2. evaluate the effect of the perceived importance of English language proficiency on the relationships of the pertinent curriculum components of TCPM.

In achieving this, the study aims to answer the following research questions:

1. What is the pertinent objective, content of learning, method of delivery and assessment method of TCPM?

2. What is the effect of the perceived importance of English language proficiency on the relationships of the pertinent curriculum components of TCPM?

\section{Study model and hypotheses}

The proposed initial model, as presented in Fig. 1, is developed based on an extensive review of the literature. The following hypotheses are to evaluate the overall model.

a. Hypothesis $1_{0}\left(\mathrm{H}_{0}\right)$ : The pertinent objective has no positive and significant effect on the TCPM for the Malaysian vocational colleges

b. Hypothesis $2_{0}\left(\mathrm{H}_{2}\right)$ : The pertinent content of learning has no positive and significant effect on the TCPM for the Malaysian vocational colleges

c. Hypothesis $3_{0}\left(\mathrm{H}_{3}\right)$ : The pertinent method of delivery has no positive and significant effect on the TCPM for the Malaysian vocational colleges

d. Hypothesis $4_{0}\left(\mathrm{H}_{0}\right)$ : The pertinent assessment method has no positive and significant effect on the TCPM for the Malaysian vocational colleges.

In addition, to test the mediation effect for the proposed model, the null hypotheses are:

a. Hypothesis $5_{0}\left(\mathrm{H}_{0}\right)$ : The relationship between pertinent objective and the TCPM for the Malaysian vocational colleges is not positively mediated by English language proficiency.

b. Hypothesis $6_{0}\left(\mathrm{H}_{0}\right)$ : The relationship between pertinent content of learning and the TCPM for the Malaysian vocational colleges is not positively mediated by English language proficiency.

c. Hypothesis $7_{0}\left(\mathrm{H}_{0}\right)$ : The relationship between pertinent method of delivery and the TCPM for the Malaysian vocational colleges is not positively mediated by English language proficiency.

d. Hypothesis $8_{0}\left(\mathrm{H}_{0}\right)$ : The relationship between pertinent assessment method and the TCPM for the Malaysian 


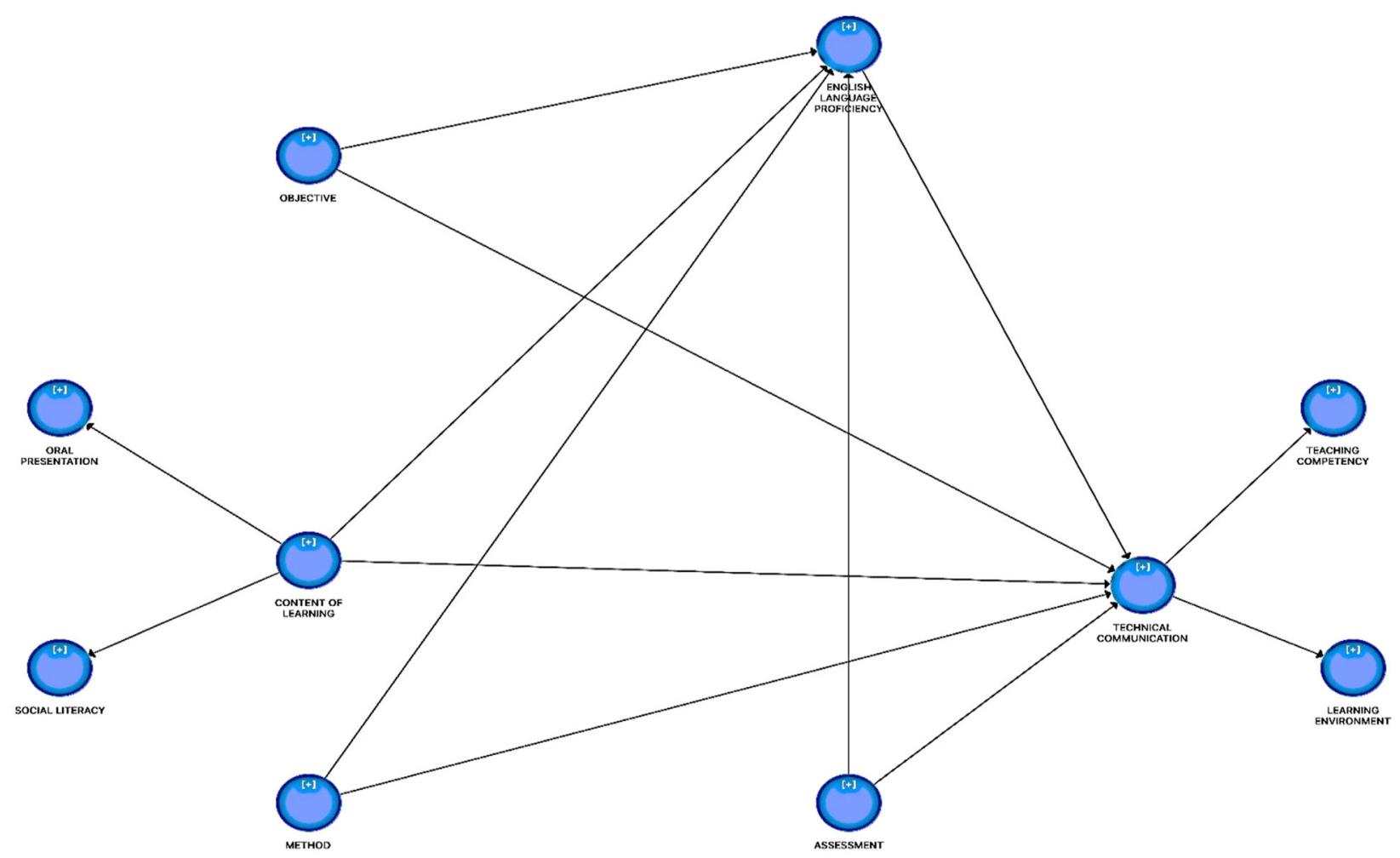

Fig. 1 The proposed initial measurement model. Representation of the four exogenous constructs (objective, content of learning, method, and assessment), the mediator (English language proficiency) and the endogenous construct (technical communication).

vocational colleges is not positively mediated by English language proficiency.

\section{Methodology}

The TCPM survey was administered to the English language instructors in the Malaysian Vocational Colleges. This is to help gather gaining insights directly from the target population and to generalize to the population (Chua, 2010). For the analysis and model development, the partial least square-structural equation modeling (PLS-SEM) analysis, using Smart-PLS was employed. This analysis was selected as the current study is exploratory in nature and has limited sample size (Ramayah et al., 2018).

Participants. For this study, 205 from 435 English language instructors across 81 Malaysian vocational colleges were selected as the research participants. The number of research participants conformed the Krejcie and Morgan's (1970) guideline for sample size determination $(N=435 ; S=205)$, and the minimum number of 150 respondents for SEM study (Hair et al., 2010).

The participants were selected using a stratified random sampling method. The calculation for stratified sampling is based on Er's (2012) suggestion:

$$
\begin{gathered}
\text { (total of required sample/population }) \times \\
(\text { total of instructors in one sub population }) \\
=\text { number of respondents to be randomly selected }
\end{gathered}
$$

Table 2 presents a summary of the required sample size according to six zones.

Majority of the respondents were female $(N=163)$, and only 42 were male. Most of them $(N=52)$ have working experience between 11 and 15 years. 46 respondents have working

\begin{tabular}{|c|c|c|}
\hline Zone/subpopulation & $\begin{array}{l}\text { Number of } \\
\text { instructors }\end{array}$ & $\begin{array}{l}\text { Number of } \\
\text { respondents }\end{array}$ \\
\hline Northern & 117 & 55 \\
\hline Central & 57 & 27 \\
\hline Southern & 95 & 45 \\
\hline East coast & 91 & 43 \\
\hline Sabah & 39 & 18 \\
\hline Sarawak & 36 & 17 \\
\hline Total & 435 & 205 \\
\hline
\end{tabular}
experience between 16 and 20 years; 31 with $<5$ years of working experience; 27 respondents with 21-25 years of working experience; 22 respondents with working experience between 26 and 30 years, and only 15 respondents with working experience between six to ten years.

Instrument. The survey instrument was initially developed based on an extensive review of the literature and validated for content validity by seven experts from TVET, local industry and English language in TVET institutions. These experts have more than 10 years of working experiences in their respective fields. This process is to ensure that the concept and information from the literature are accurately interpreted in the instrument (Drost, 2011).

The experts suggested adding a number of items such as the ability to produce marketing literature, and the use of online and contextualized learning activities. However, they also suggested removing an item: the ability to deliver a speech to the audience. After modification based on the experts' suggestions, the instrument has been piloted face-to-face, on 100 English language instructors, to ensure a high return rate and understanding of the instrument (Chua, 2010). Overall, the instrument has four sections: (1) Section A: Demographic Information (four items); 
Table 3 The Cronbach's alpha measure of reliability.

\begin{tabular}{lll} 
Section & Construct & Cronbach's alpha value \\
\hline B1 & Objective & 0.896 \\
B2.1 & Social literacy skills (content of learning) \\
B2.2 & Oral presentation skills (content of learning) \\
B3 & Method of delivery & 0.935 \\
B4 & Assessment method & 0.874 \\
C1 & Learning environment (perceived importance of technical communication pedagogical model) \\
C2 & Teaching competency (perceived importance of technical communication pedagogical model) \\
D & Perceived importance of English language proficiency
\end{tabular}

(2) Section B: B1. Objective (seven items), B2. Content of learning (17 items), B3. Method of delivery (six items) and B4. Assessment method (five items); (3) Section C: C1. Learning Environment. (eight items) and C2. Teaching competency (four items), and (4) Section D: English language proficiency (three items).

The result of the reliability analysis is presented in Table 3. Overall, the alpha value for each construct was between 0.671 and 0.949 .

The findings in Table 3 has indicated that this instrument has achieved a good internal consistency, where the values were above 0.60 and did not exceed 0.95 (Hair et al., 2017).

\section{Results}

Initial model. The findings in Table 4 indicated that all constructs have achieved internal consistency reliability. The Cronbach's alpha values for all constructs have exceeded the recommended threshold value of 0.60 (Hair et al., 2006). The outer loading values for all item in each construct were above the recommended threshold value of 0.40 (Chin, 1998). In addition, the $\mathrm{CR}$ values for all constructs were above 0.70 , indicating a good reliability (Chin, 1998). However, teaching competency construct should be treated with caution as the value of CR was higher than 0.95 , indicating a possibility of redundant items in this construct (Hair et al., 2017). Figure 2 provides a summary of the initial measurement model.

The results also indicated that all constructs have achieved a good convergent validity, with average variance extracted (AVE) values above 0.50 (Garson, 2016). However, there were a number of items that have outer loading lower than 0.70 , and thus should be treated with caution.

Also, the discriminant validity for all constructs was identified based on the Fornell and Larcker's (1981) criterion, and heterotrait-monotrait ratio (HTMT). Table 5 provides a summary of the results of Fornell and Larcker's (1981) criterion analysis. The correlation values between all constructs were lower compared to every construct squared AVE value, indicating all constructs have achieved discriminant validity. In addition, the findings of HTMT analysis in Table 6 indicated that all constructs have achieved HTMT values lower than the recommended threshold value of 0.85 (Kline, 2011), except for Method construct (0.871). It was found that one item in this construct (MET6) loaded higher than an item in Assessment construct. Therefore, this item was considered for deletion.

Measurement model. Modification of the initial measurement model includes the deletion of: (a) lower factor loading $(<0.70)$ such as item COL7, COL17, MET1, MET4, and ASM5, (b) almost semantically identical items (TC1: The pedagogical model will help to improve teachers' understanding of relevant communication skills to the current industry, or TC2: The pedagogical model will help to improve teachers' understanding of relevant communication skills to the current industry), and (c) item with
Table 4 Assessment of the initial measurement model.

\begin{tabular}{lllll} 
Construct & Outer loading & Cronbach's alpha & CR & AVE \\
\hline Objective & $0.710-0.848$ & 0.895 & 0.917 & 0.613 \\
Oral presentation & $0.692-0.838$ & 0.905 & 0.923 & 0.602 \\
Social literacy & $0.567-0.870$ & 0.922 & 0.937 & 0.624 \\
Method & $0.674-0.810$ & 0.819 & 0.869 & 0.526 \\
$\begin{array}{l}\text { Assessment } \\
\text { Teaching } \\
\text { competency }\end{array}$ & $0.602-0.839$ & 0.806 & 0.867 & 0.569 \\
Learning & $0.736-0.890$ & 0.946 & 0.955 & 0.726 \\
environment & $0.813-0.910$ & 0.894 & 0.927 & 0.760 \\
$\begin{array}{l}\text { English language } \\
\text { proficiency }\end{array}$ & $0.803-0.874$ & 0.776 & 0.870 & 0.690 \\
\hline
\end{tabular}

higher cross-loading value (MET6). The modification has improved the reliability of all construct (refer Table 7). For instance, all items have a higher outer loading value, between 0.602 and 0.910 , acceptable Cronbach's alpha values, between 0.727 and 0.928 , and ideal CR values, between 0.847 and 0.941 .

In addition, the AVE values were between 0.569 and 0.760 , providing evidence of convergent validity (AVE > 0.50) (Garson, 2016). On the other hand, the correlation values between all constructs were lower compared to every construct squared AVE, as presented in Table 8. Evidently, the results indicated that all constructs have achieved discriminant validity based on the Fornell and Larcker's (1981) criterion. Also, the findings of the HTMT analysis (refer Table 9) indicated that all constructs have achieved lower than 0.85 and the cross-loading value for all items were lower than in its construct, providing an evidence of a good discriminant validity (Kline, 2011).

The results for the higher-order constructs (HOCs) are presented in Table 10. Evidently, the HOCs have achieved: (1) acceptable outer loading value (between 0.662 and 0.841 ), (2) acceptable Cronbach's alpha value, above 0.6, and (3) ideal CR with 0.949 for technical communication and 0.950 for content of learning. These provided evidence of a good reliability.

The results have provided evidence of convergent validity for the HOCs. For instance, the AVE for Content of learning was 0.560 , and Technical communication was 0.652 , which exceeded the recommended threshold value of 0.50 (Garson, 2016). In addition, the outer loadings were above the acceptable value of 0.40 (Hulland, 1999).

The HOCs have also achieved discriminant validity. Based on the Fornell and Larcker's (1981) criterion, the values of the correlation between all constructs were lower compared to every construct squared AVE (refer Table 11). In addition, as presented in Table 12, all constructs have achieved acceptable HTMT value, between 0.394 and 0.812 (HTMT < 0.85), indicating evidence of good discriminant validity (Kline, 2011). 


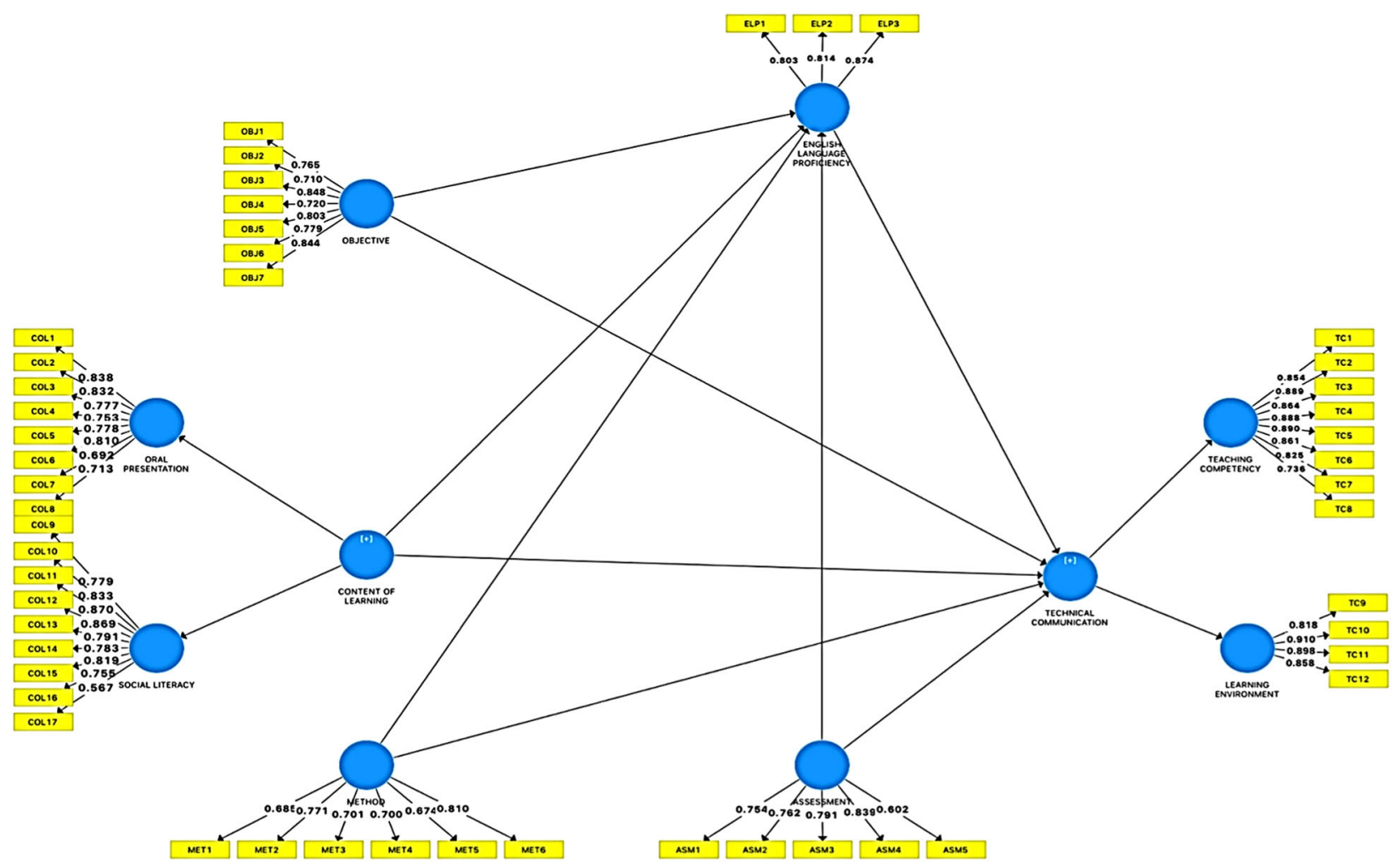

Fig. 2 The initial measurement model. The constructs and indicators for each construct with their loading values.

Table 5 The Fornell and Larcker's (1981) criterion analysis for the initial measurement model.

\begin{tabular}{|c|c|c|c|c|c|c|c|c|}
\hline Assessment & 0.754 & & & & & & & \\
\hline $\begin{array}{l}\text { English language } \\
\text { proficiency }\end{array}$ & 0.482 & 0.831 & & & & & & \\
\hline $\begin{array}{l}\text { Teaching } \\
\text { competency }\end{array}$ & 0.598 & 0.561 & 0.852 & & & & & \\
\hline Method & 0.717 & 0.481 & 0.623 & 0.725 & & & & \\
\hline Social literacy & 0.500 & 0.476 & 0.548 & 0.633 & 0.563 & 0.742 & 0.790 & \\
\hline $\begin{array}{l}\text { Learning } \\
\text { environment }\end{array}$ & 0.576 & 0.451 & 0.748 & 0.543 & 0.377 & 0.506 & 0.483 & 0.872 \\
\hline
\end{tabular}

Table 6 The HTMT analysis for the initial measurement model.

\begin{tabular}{|c|c|c|c|c|c|c|c|c|}
\hline \multicolumn{9}{|l|}{ Assessment } \\
\hline $\begin{array}{l}\text { English language } \\
\text { proficiency }\end{array}$ & 0.611 & & & & & & & \\
\hline $\begin{array}{l}\text { Teaching } \\
\text { competency }\end{array}$ & 0.679 & 0.651 & & & & & & \\
\hline Method & 0.871 & 0.590 & 0.700 & & & & & \\
\hline Social literacy & 0.581 & 0.558 & 0.588 & 0.726 & 0.619 & 0.812 & & \\
\hline $\begin{array}{l}\text { Learning } \\
\text { environment }\end{array}$ & 0.675 & 0.540 & 0.811 & 0.622 & 0.412 & 0.561 & 0.530 & \\
\hline
\end{tabular}


In addition, all four LOCs have a significant relationship with their respective HOCs, with $t$-value above 1.96 and were significant at 0.01 value (Hair et al., 2017), as presented in Table 13. These results provide evidence of significant relationships between HOCs with their respective LOCs.

In addition, all four LOCs have a significant relationship with their respective HOCs, with $t$-value above 1.96 and were significant at 0.01 value (Hair et al., 2017). These results provide evidence of significant relationships between HOCs with their respective LOCs.

The structural model. The analysis of multicollinearity through the identification of variance inflation factor (VIF) indicated that

Table 7 Assessment of the measurement model.

\begin{tabular}{lllll} 
Construct & Outer loading & Cronbach's alpha & CR & AVE \\
\hline Objective & $0.709-0.845$ & 0.895 & 0.917 & 0.613 \\
Oral presentation & $0.695-0.857$ & 0.900 & 0.922 & 0.628 \\
Social literacy & $0.751-0.873$ & 0.928 & 0.941 & 0.668 \\
Method & $0.737-0.871$ & 0.727 & 0.847 & 0.649 \\
Assessment & $0.602-0.840$ & 0.806 & 0.867 & 0.569 \\
$\begin{array}{l}\text { Teaching } \\
\text { competency }\end{array}$ & $0.747-0.903$ & 0.927 & 0.943 & 0.736 \\
$\begin{array}{l}\text { Learning } \\
\text { environment }\end{array}$ & $0.819-0.910$ & 0.894 & 0.927 & 0.760 \\
$\begin{array}{l}\text { English language } \\
\text { proficiency }\end{array}$ & $0.806-0.873$ & 0.776 & 0.870 & 0.690 \\
\hline
\end{tabular}

all inner VIF values for exogenous variables were $<5.0$, indicating multicollinearity was not an issue for this model (Hair et al., 2017). Also, the significance of relationships analysis (presented in Table 14) indicated that all exogenous constructs have a significant relationship in predicting Technical communication, except for Method of delivery $(p>0.005, t<1.645)$. The analysis of relative importance showed that Assessment was the most important predictor $(0.316)$ to predict Technical communication.

Based on the above results, three null hypotheses $\left(\mathrm{H} 1_{0}, \mathrm{H} 2_{0}\right.$ and $\mathrm{H}_{4}$ ) should be rejected as these variables (Objective, Content of learning, and Assessment) have positive and significant effect on Technical communication. However, one null hypothesis $\left(\mathrm{H} 2_{0}\right)$ was accepted as the Method of delivery construct have no positive and significant effect on Technical communication.

On the other hand, Table 15 presents the results of predictive accuracy $\left(R^{2}\right)$ and relevance $\left(Q^{2}\right)$. The model has achieved the $R^{2}$ value of 0.526 , indicating a substantial level of predictive accuracy (Cohen, 1988). Also, the predictive relevance $Q^{2}$ value was 0.316 , which exceeded the 0.00 cut-off value (Cohen, 1988). This indicated that the model is predictive by exogenous variables in this study.

Other than that, Table 16 presents the results of the effect size assessment. All exogenous constructs, except Method have achieved small effect size between 0.027 and 0.116 (Cohen, 1988) in producing $R^{2}$ for Technical communication. Figure 3 shows a summary of the structural model results.

Mediation analysis. In this study, the relevant skills to English language proficiency are believed to be important in developing

Table 8 The Fornell and Larcker's (1981) criterion analysis for the measurement model.

\begin{tabular}{|c|c|c|c|c|c|c|c|c|}
\hline & Assessment & $\begin{array}{l}\text { English language } \\
\text { proficiency }\end{array}$ & $\begin{array}{l}\text { Learning } \\
\text { environment }\end{array}$ & Method & Objective & $\begin{array}{l}\text { Oral } \\
\text { presentation }\end{array}$ & $\begin{array}{l}\text { Social } \\
\text { literacy }\end{array}$ & $\begin{array}{l}\text { Teaching } \\
\text { competency }\end{array}$ \\
\hline Assessment & 0.754 & & & & & & & \\
\hline $\begin{array}{l}\text { English language } \\
\text { proficiency }\end{array}$ & 0.483 & 0.831 & & & & & & \\
\hline $\begin{array}{l}\text { Teaching } \\
\text { competency }\end{array}$ & 0.576 & 0.451 & 0.872 & & & & & \\
\hline Method & 0.681 & 0.455 & 0.523 & 0.782 & & & & \\
\hline Objective & 0.348 & 0.280 & 0.377 & 0.431 & 0.783 & & & \\
\hline Oral presentation & 0.559 & 0.501 & 0.497 & 0.641 & 0.585 & 0.793 & & \\
\hline Social literacy & 0.496 & 0.478 & 0.477 & 0.625 & 0.540 & 0.726 & 0.817 & \\
\hline $\begin{array}{l}\text { Learning } \\
\text { environment }\end{array}$ & 0.572 & 0.547 & 0.744 & 0.593 & 0.467 & 0.590 & 0.529 & 0.858 \\
\hline
\end{tabular}

Table 9 The HTMT analysis for the measurement model.

\begin{tabular}{|c|c|c|c|c|c|c|c|c|}
\hline & Assessment & $\begin{array}{l}\text { English language } \\
\text { proficiency }\end{array}$ & $\begin{array}{l}\text { Learning } \\
\text { environment }\end{array}$ & Method & Objective & $\begin{array}{l}\text { Oral } \\
\text { presentation }\end{array}$ & $\begin{array}{l}\text { Social } \\
\text { literacy }\end{array}$ & $\begin{array}{l}\text { Teaching } \\
\text { competency }\end{array}$ \\
\hline \multicolumn{9}{|l|}{ Assessment } \\
\hline $\begin{array}{l}\text { English language } \\
\text { proficiency }\end{array}$ & 0.611 & & & & & & & \\
\hline $\begin{array}{l}\text { Learning } \\
\text { environment }\end{array}$ & 0.675 & 0.540 & & & & & & \\
\hline Method & 0.786 & 0.546 & 0.554 & & & & & \\
\hline Objective & 0.394 & 0.326 & 0.412 & 0.539 & & & & \\
\hline Oral presentation & 0.652 & 0.594 & 0.552 & 0.789 & 0.641 & & & \\
\hline Social literacy & 0.574 & 0.560 & 0.521 & 0.746 & 0.584 & 0.791 & & \\
\hline $\begin{array}{l}\text { Teaching } \\
\text { competency }\end{array}$ & 0.657 & 0.642 & 0.813 & 0.633 & 0.501 & 0.644 & 0.569 & \\
\hline
\end{tabular}




\section{Table 10 Assessment of the HOCs.}

\begin{tabular}{lllll} 
Construct & Outer loading & Cronbach's alpha & CR & AVE \\
\hline $\begin{array}{l}\text { Content of } \\
\text { learning }\end{array}$ & $0.662-0.819$ & 0.944 & 0.950 & 0.560 \\
$\begin{array}{l}\text { Technical } \\
\text { communication }\end{array}$ & $0.713-0.841$ & 0.940 & 0.949 & 0.652 \\
\hline
\end{tabular}

Technical communication. The mediation analysis was conducted, and the results suggested that both Content of learning and assessment were mediated by English language proficiency (refer Table 17). Both constructs have achieved a significant value of indirect (Content of learning with $t=2.376, p<0.01$; Assessment with $t=1.875, p<0.05$ ) and direct effect (Content of learning with $t=1.852, p<0.05$; Assessment with $t=4.196$, $p<0.01)$.

\begin{tabular}{|c|c|c|c|c|c|c|}
\hline & Assessment & Content of learning & English language proficiency & Method & Objective & Technical \\
\hline Assessment & 0.754 & & & & & \\
\hline Content of Learning & 0.565 & 0.749 & & & & \\
\hline English Language Proficiency & 0.483 & 0.526 & 0.831 & & & \\
\hline Method & 0.606 & 0.669 & 0.418 & 0.806 & & \\
\hline
\end{tabular}

Table 12 Discriminant validity result based on the HTMT analysis for the HOCs.

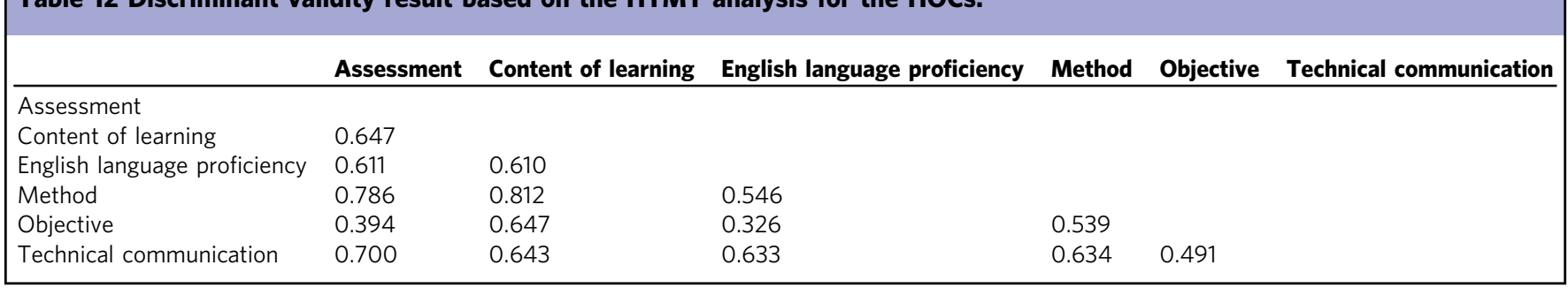

\section{Table 13 Relationship testing for the HOCs.}

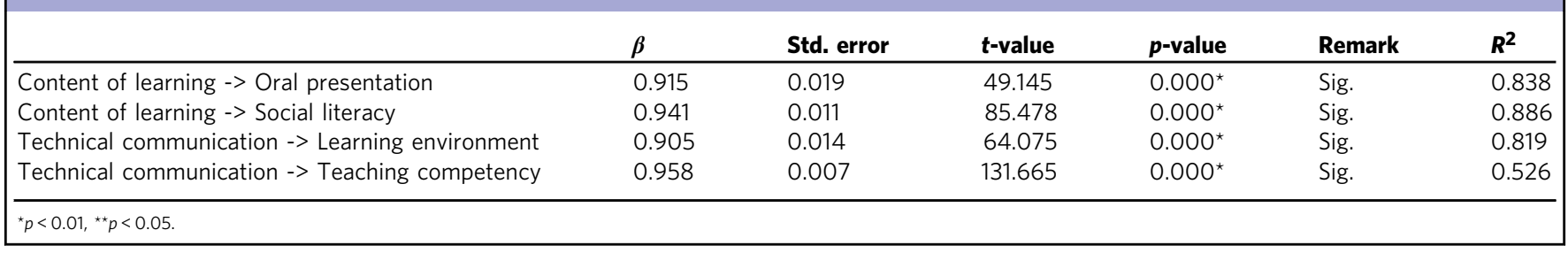

\section{Table 14 Significance of relationships for the structural model.}

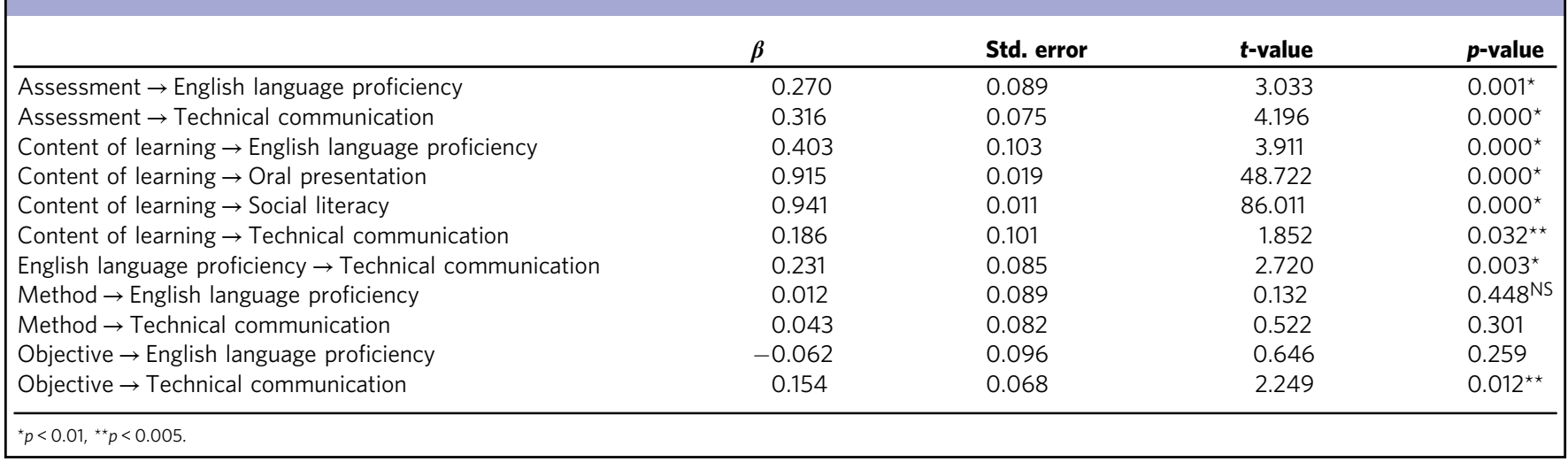


Also, the sign of $a \times b \times c^{\prime}$ for both constructs were all positive, indicating a complementary partial mediation exists (Zhao et al., 2010). Therefore, two null hypotheses $\left(\mathrm{H}_{0}\right.$ and $\left.\mathrm{H} 8_{0}\right)$ were rejected, and the other two were accepted $\left(\mathrm{H} 5_{0}\right.$ and $\mathrm{H} 7_{0}$ ).

\section{Discussion}

Pertinent elements of TCPM. The overall result of the structural analysis indicated that all constructs have a positive and significant effect on the perceived importance of TCPM (Objective: $p=0.012, t=2.249$, Content of learning: $p=0.032, t=1.852$, Assessment method: $p=0.000, t=4.196)$, except for Method of delivery $(p=0.301, t=0.522)$. The effect size of each construct

\section{Table 15 Predictive accuracy $\left(R^{2}\right)$ and predictive relevance} $\left(Q^{2}\right)$ assessment for the structural model.

\begin{tabular}{lllll|} 
& $\boldsymbol{R}^{\mathbf{2}}$ & SSO & SSE & $\begin{array}{l}\mathbf{Q}^{\mathbf{2}}(=\mathbf{1}-\mathbf{S S E} \\
\mathbf{S S O})\end{array}$ \\
\hline $\begin{array}{l}\text { Technical } \\
\text { communication }\end{array}$ & 0.526 & 2050.00 & 1402.44 & 0.316 \\
\hline
\end{tabular}

\begin{tabular}{|ll|}
$\begin{array}{l}\text { Table } \mathbf{1 6} \text { Effect size }\left(\boldsymbol{f}^{\mathbf{2}}\right) \text { assessment for the } \\
\text { structural model. }\end{array}$ \\
& Technical communication \\
\hline Assessment & 0.116 \\
Content of learning & 0.027 \\
English language proficiency & 0.075 \\
Method & 0.002 \\
Objective & 0.032 \\
\hline
\end{tabular}

was small, except Method of delivery, and the model has achieved acceptable predictive relevance. The overall components of the TCPM is presented in Table 18.

The objectives of this TCPM focus on the development of both oral presentation and social literacy skills, providing work-related and authentic communicative experiences, as well as providing guidance for English language instructors for effective implementation. These objectives reflect Wellington's (1993) suggestions for effective school-workplace competencies development. The curriculum should provide work-based activities that help to develop their work-related competencies, including communication, as suggested in the previous literature (Mourshed et al., 2014; Nagendra et al., 2013; Oxtoby, 1997; Tabbron and Yang, 1997).

For Content of learning, the ability to retrieve, gather and organize information, distinguish main ideas in a text and awareness of how technological tools help to promote interactions, as well as to plan and develop introduction, content and conclusion of the presentation, should be the focus for oral presentation skills development. Also, the content should include an introduction to social literacy skills such as the ability to communicate and establish a relationship with customer and coworkers, give instruction and constructive feedback, and multicultural awareness. These findings are in line with the suggestions by Lappalainen (2010), Brinkman and van der Geest (2003), and Cook (2002), as they mentioned that these skills are pivotal to enhance students' employability skills. In the localized context of Malaysia, the proposed content reflects the current needs in the local industry as the employers expected graduates to have interpersonal, social skills, and multicultural awareness (Muda et al., 2012; Rasul et al., 2013; Singh et al., 2014; Zaharim et al., 2012).

Interestingly, the ability to produce business letters was not significant to this model. However, this is not a surprising fact as recent studies in the context of Malaysian TVET noted that the

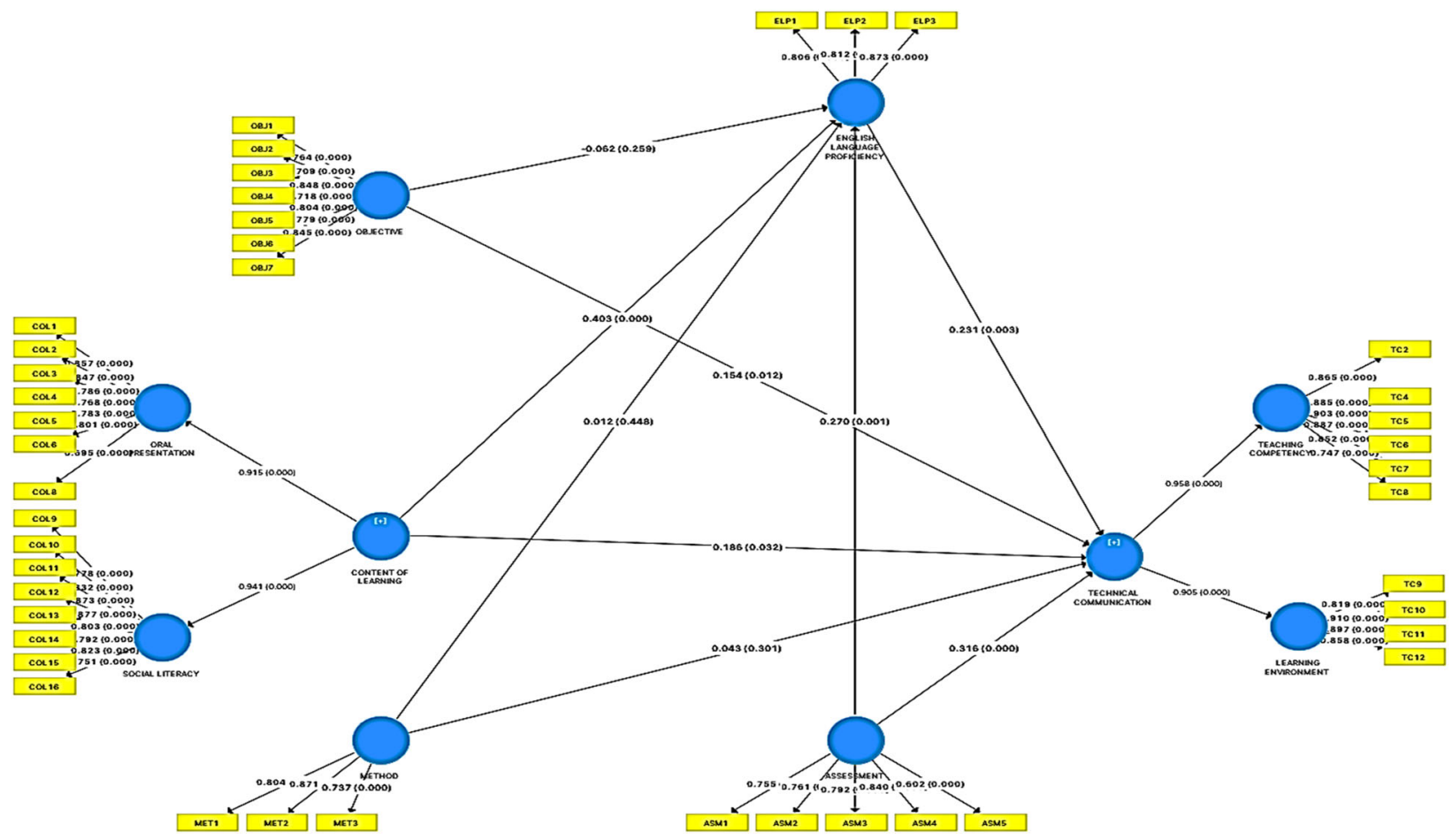

Fig. 3 The structural model. The summary of the structural model analysis with the loading values between the indicators and each construct and the coefficient values between constructs. 
Table 17 Mediation analysis result.

\begin{tabular}{|c|c|c|c|c|}
\hline & $\beta$ & Std. error & t-value & $p$-value \\
\hline Objective $\rightarrow$ English language proficiency & -0.062 & 0.096 & 0.646 & 0.259 \\
\hline Content of learning $\rightarrow$ English language proficiency & 0.403 & 0.103 & 3.911 & $0.000^{*}$ \\
\hline Assessment $\rightarrow$ English language proficiency & 0.270 & 0.089 & 3.033 & $0.001^{\star}$ \\
\hline \multicolumn{5}{|l|}{ Path $b$} \\
\hline English language proficiency $\rightarrow$ Technical communication & 0.231 & 0.085 & 2.720 & $0.003^{\star}$ \\
\hline Content of learning $\rightarrow$ Technical communication & 0.186 & 0.101 & 1.852 & $0.032^{\star \star}$ \\
\hline Method $\rightarrow$ Technical communication & 0.043 & 0.082 & 0.522 & 0.301 \\
\hline Assessment $\rightarrow$ Technical communication & 0.316 & 0.075 & 4.196 & $0.000^{\star}$ \\
\hline \multicolumn{5}{|l|}{ Total effect } \\
\hline Objective $\rightarrow$ Technical communication & 0.140 & 0.077 & 1.809 & $0.035^{\star \star}$ \\
\hline Content of learning $\rightarrow$ Technical communication & 0.280 & 0.096 & 2.908 & $0.002^{\star}$ \\
\hline Content of learning $\rightarrow$ English language proficiency $\rightarrow$ Technical communication & 0.0930 & 0.0390 & 2.376 & $0.009^{\star}$ \\
\hline Method $\rightarrow$ English language proficiency $\rightarrow$ Technical communication & 0.0030 & 0.0210 & 0.129 & 0.449 \\
\hline Assessment $\rightarrow$ English language proficiency $\rightarrow$ Technical communication & 0.0620 & 0.0330 & 1.875 & $0.030^{\star \star}$ \\
\hline
\end{tabular}

local industry only expects basic writing skills among TVET graduates (Muda et al., 2012; Rasul et al., 2013).

In the Malaysian vocational colleges, the assessment of technical communication can be conducted through oral presentation, writing technical documents, as well as an observation on students' communication during group work, field training, and online forum. Since traditional assessment such as examination is less relevant in the Malaysian TVET context (Department of Skills Development Malaysia, 2016; Singh et al., 2012), the proposed assessment methods are found to be more relevant. To support, Rahman et al. (2014) agreed that formal examination should be replaced with more authentic assessments, especially in assessing students' employability skills, including communication skills. They suggested competency-based assessments which are similarly proposed in this study as relevant assessment methods in Malaysian vocational colleges.

Initially, the suggested methods of delivery such as practical tutorials, collaborative learning activities, and field training were derived from the previous studies on technical communication delivery in the international context (Lappalainen, 2010; Reaves, 2004; Laverty, 1979). These methods are found to be beneficial in encouraging independent and collaborative learning skills development. However, this construct was insignificant $(p=0.301$, $t=0.522$ ). A possible explanation to this interesting finding is the poor monitoring and support received by English language instructors in Malaysian vocational colleges. Mahmud and Ismail (2010) and Alazam Bakar et al. (2012) found that these instructors were burdened with overbearing workloads and have very limited time at work to prepare active and interesting teaching and learning activities for students (Abdul-Wahab et al., 2010). As a result, they opted for traditional chalk-and-talk teaching.

Effect of English language proficiency on TCPM. The findings in the current study indicated that English language proficiency only functioned as complementary partial mediator for both Content of learning $(t=2.376, p=0.009 ; t=1852, p=0.032)$ and Assessment $(t=1.875, p=0.030 ; t=4.196, p=0.000)$.
Language skills such as the ability to use accurate sentence structure, apply appropriate verbal communication strategy and comprehend information were found important for Content of learning and Assessment method. This is in line with suggestions to include English proficiency skills in technical communication skills development (Brinkman and van der Geest, 2003; Cook, 2002; Lappalainen, 2010).

Clearly, Technical communication falls under the ESP concept. Technical communication has both absolute and variable characteristics of ESP (Strevens, 1988). In this study, TCPM is aimed to serve as a reference in developing students' communication-for-work skills, which were found to be lacking among graduates (Hanapi and Nordin, 2014; Osman et al., 2015; Shuib, 2005). Interestingly, the current study also found that English language proficiency skills should be embedded through the process of teaching and learning. This is because these skills will help to enhance communication for work (Brinkman and van der Geest, 2003; Laverty, 1979; McMurrey, 2002; Nutman, 1987). To support, in the communication process model, Dean and Bryson (1961) highlighted the importance of acquiring a good "language system" to enhance the communication process.

\section{Conclusion}

Technical communication reflects the actual communicative experiences that happened in the industry (Brinkman and van der Geest, 2003; Reaves, 2004; Rus, 2014). Therefore, TVET graduates should be able to master the skills. However, in the current curriculum in Malaysian vocational colleges, little emphasis is given in developing this skill. In this study, the proposed model has achieved a moderate level of coefficient of determination $\left(R^{2}=0.526\right)$, small effect size for almost all curriculum constructs, and an acceptable value of predictive relevance $\left(Q^{2}=0.316\right)$. These indicate that the model can serve as a relevant reference for the implementation of technical communication skills development in these institutions. Even though, the Method of delivery was insignificant $(p=0.301, t=0.522)$, the proposed methods such as practical tutorials, collaborative 
Table 18 The proposed components for technical communication pedagogical model.

\section{Objective}

1. Develop oral communication skills that are relevant to the industry.

2. Develop written communication skills that are relevant to the industry.

3. Develop interpersonal skills that are relevant to the industry.

4. Develop researching skills that are relevant to the industry.

5. Provide work-related communicative experiences for students.

6. Guide teaching and learning for communication skills in the technical field.

7. Expose students with authentic communicative experiences in the real settings of the industry.

Content of learning: Oral presentation

1. Develop the ability to retrieve relevant information.

2. Develop the ability to gather and organize relevant information.

3. Develop the ability to distinguish main ideas from supporting details.

4. Develop knowledge on how to operate technological tools.

5. Develop awareness of how technological tools help to promote social interactions and collaboration at work.

6. Develop the ability to plan and develop the content of oral presentations.

7. Develop the ability to plan and prepare visual aids (for a larger audience).

8. Develop the ability to plan an introduction and conclusion of oral presentations.

Content of learning: Social literacy

1. Develop the ability to communicate effectively with co-workers and administrators.

2. Develop the ability to give instructions effectively.

3. Develop the ability to give constructive feedback.

4. Develop the ability to establish professional relationships with customers and co-workers.

5. Develop the ability to share information in small group settings.

6. Develop multicultural awareness.

7. Develop the ability to handle conflicts within groups positively.

8. Develop leadership skills.

9. Develop the ability to produce business letters.

Method of delivery (insignificant)

1. Delivering the content through a practical tutorial.

2. Delivering the content through a collaborative learning activity.

3. Delivering the content through field training.

4. Delivering the content through the communication module which introduces technical communication across technical subjects.

5. Delivering the content through communication across the curriculum (integrates technical communication skills across technical subjects).

6. Delivering the content through contextualized learning activity (which is conducted in an authentic working environment).

Assessment method

1. Assessment on students' oral presentations.

2. Assessment on students' written technical documents.

3. Observation on students' communicative experiences during field work training.

4. Observation on students' communicative experiences in group activities / team work projects.

5. Assessment on students' responses in online forum discussion.

English language proficiency

1. Developing the ability to construct accurate sentence structure in writing.

2. Developing the ability to apply appropriate verbal communication strategy in a conversation.

3. Developing the ability to comprehend information in a text in English language.

learning activities, and field training can be considered to replace the traditional teaching method practised in the institutions. On the other hand, English language proficiency skills such as the ability to use accurate sentence structure, apply appropriate verbal communication strategy, and comprehend information was found to be a complementary partial mediator for both Content of learning $(t=2.376, p=0.009 ; t=1852$, $p=0.032)$ and Assessment $(t=1.875, p=0.030 ; t=4.196$, $p=0.000$ ). This indicates that these skills should be considered as part of technical communication skills development.

\section{Data availability}

The datasets generated during and/or during the current study are not publicly available due to confidentiality of the respondents' information but are available from the corresponding author on reasonable request.

Received: 8 March 2020; Accepted: 4 September 2020;

Published online: 30 September 2020

\section{References}

Alazam A, Bakar A, Hamzah R, Asmiran S (2012) Teachers' ICT skills and ICT integration in the class- room: the case of vocational and technical teachers in Malaysia. Creat Educ 3:70-76

Batista S, Behar P, Passerino L (2010) Use of Graph2Go in M-Learning: a view from the pedagogical model. In: Reynolds N, Turcsányi-Szabó M (eds) IFIP international conference on key competencies in the knowledge society, Brisbane, Australia, September 2010. IFIP advances in information and communication technology, vol 324. Springer, Berlin, Heidelberg, p 12 Proceedings of the 3rd IFIP TC international conference, KCKS, World Computer Congress, Brisbane, Australia

Brinkman GW, van der Geest TM (2003) Assessment of communication competencies in engineering design projects. Tech Commun Q 12:67-81

Chua YP (2010) Mastering research methods. McGraw-Hill Education, Kuala Lumpur

Chin WW (1998) The partial least squares approach for structural equation modeling. In: Macoulides GA (ed) Modern methods for business research. Lawrence Erlbaum Associates, Mahwah, pp 295-336

Cohen J (1988) Statistical power analysis for the behavioural science, 2nd edn. Lawrence Erlbaum Associates, Hillsdale

Cook KC (2002) Layered literacies: a theoretical frame for technical communication pedagogy. Tech Commun Q 11:5-29

Dean HH, Bryson KD (1961) Effective communication, 2nd edn. Prentice-Hall, Inc, Englewood 
Department of Skills Development Malaysia (2016) National Occupational Skills Standard (NOSS) Registry 24 Mei 2016. Department of Skills Development Malaysia, Putrajaya

Department of Statistics Malaysia (2016) Labour force by highest certification. https://www.statistics.gov.my/index.php? $\mathrm{r}=$ column/cthree\&menu_id= cEhBV0xzWll6WTRjdkJienhoR290QT09. Accessed 14 Aug 2017

Department of Statistics Malaysia (2017) Labour force survey report, Malaysia, 2016. https://www.dosm.gov.my/v1/index.php?r=column/pdfPrev\&id=SGZ CNnMrWW9ZTEdpYys4YW0yRlhoQT09. Accessed 14 Aug 2017

Department of Statistics Malaysia (2018) Principal Statistics of Labour Force Malaysia, 2017. https://www.dosm.gov.my/v1/index.php?r=column/ pdfPrev\&id=U243VmM4VHJHMXJKaUVvMjZwaDdhdz09. Accessed 12 May 2019

Department of Statistics Malaysia (2019) Key statistics of labour force in Malaysia, October 2019. https://www.dosm.gov.my/v1/index.php? $\mathrm{r}=$ column/pdfPrev\&id=ZkhCUHpVT0NkbnliUVFITjBwUG1qdz09. Accessed 20 Jul 2019

Drost EA (2011) Validity and reliability in social science research. Educ Res Perspect 38:105-123

Dobbs R, Madgavkar A (2014) The world at work: matching skills and jobs in Asia. Prospects 44:197-210

Er S (2012) Comparison of the efficiency of the various algorithms in stratified sampling when the initial solutions are determined with geometric method. Int J Stat Appl 2:1-10

Fornell C, Larcker DF (1981) Evaluating structural equation models with unobservable variables and measurement errors. J Market Res 18:39-50

Garson GD (2016) Partial least squares regression and structural equation models, 2nd edn. Statistical Associates, Asheboro

Hair JF, Black WC, Babin BJ, Anderson RE, Tatham RL (2006) Multivariate data analysis, 6th edn. Pearson Education, Inc., Upper Saddle River, NJ

Hair JF, Black WC, Babin BJ, Anderson RE (2010) Multivariate data analysis, 7th edn. Prentice-Hall, Englewood Cliffs, NJ

Hair JF, Hult GTM, Ringle CM, Sarstedt M (2017) A primer on partial least squares structural equation modeling (PLS-SEM), 2nd edn. Sage, Thousand Oaks

Hanapi Z, Nordin MS (2014) Unemployment among Malaysia graduates: graduates' attributes, lecturers' competency and quality of education. ProcediaSoc Behav Sci 112:1056-1063

Hasmori AA, Yunos JM, Hamza R, Aripin MA (2014) Revealed knowledge integration in National Dual Training System (NDTS): philosophy, issues, and challenges. Procedia-Soc Behav Sci 204:191-197

Hulland J (1999) Use of partial least squares (PLS) in strategic management research: a review of four recent studies. Strat Manag J 20:195-204

Ibrahim MZ, Rahman MNA, Yasin RM (2012) Assessing students' perceptions of service quality in technical educational and vocational training (TEVT) institutions in Malaysia. Procedia Soc Behav Sci 56:272-283

Kline R (2011) Principles and practices of structural equation modeling, 3rd edn. The Guilford Press, New York

Krejcie RV, Morgan DW (1970) Determining sample size for research activities. Educ Psychol Meas 30:607-610

Kunioshi N, Noguchi J, Hayashi H, Tojo K (2012) An online site for preparation of oral presentations in science and engineering. Eur J Eng Educ 37(6):600-608

Lappalainen P (2010) Integrated language education-a means of enhancing engineers' social competences. Eur J Eng Educ 35(4):393-403

Laverty SJ (1979) Communication skills at the Ulster Polytechnic. Eur J Eng Educ 4:131-137

Mahmud R, Ismail MA (2010) Impact of training and experience in using ICT on in-service teachers' basic ICT literacy. Malays J Educ Technol 10(2):5-10

McMurrey DA (2002) Power tools for technical communication. Harcourt, Inc, Sea Harbor Drive, Orlando

Ministry of Education Malaysia (2012) Preliminary report: Malaysia education blueprint 2013-2025. http://www.moe.gov.my/userfiles/file/PPP/PreliminaryBlueprint-Eng.pdf. Accessed 20 Jul 2016

Ministry of Education Malaysia (2014a) Dokumen kurikulum standard Kolej Vokasional: Modul Akademik Bahasa Inggeris, General English (Standard curriculum document for Vocational Colleges: academic module English language, General English). Kementerian Pendidikan Malaysia, Putrajaya

Ministry of Education Malaysia (2014b) Dokumen kurikulum standard Kolej Vokasional: Modul akademik bahasa inggeris, English for Communication (Standard curriculum document for Vocational Colleges: academic module English language, English for Communication). Kementerian Pendidikan Malaysia, Putrajaya

Ministry of Education Malaysia (2014c) Dokumen kurikulum standard Kolej Vokasional: Modul akademik bahasa inggeris, English for specific purposes (Standard curriculum document for vocational colleges: academic module English language, English for specific purposes). Kementerian Pendidikan Malaysia, Putrajaya

Mitchell J (1962) Handbook of technical communication. Wadsworth Publishing Company, Inc, Belmont

Mourshed M, Patel J, Suder K (2014) Education to employment: getting Europe's youth into work. McKinsey \& Company, New York City
Muda N, Din UKS, Majid N, Ahmad RR, Shahabudin FAA, Rambely AS, Suradi $N R M(2012)$ Industrial training as a benchmark of the employability for the mathematical sciences students of UKM. Procedia Soc Behav Sci 59:598-603

Minghat AD, Yasin RM (2010) Sustainable framework for technical and vocational education in Malaysia. Procedia Soc Behav Sci 9:1233-1237

Nagendra KM, Naidu CG, Radha S (2013) Vocational Value Vector (V3) management in technical vocational education and training (TVET) for enhanced industrial employability. In: Mukhopadhyay C, Akhilesh KB, Srinivasan R, Gurtoo A, Ramachandran P, Iyer PP, Mathirajan M, Subrahmanya MHB (eds) Driving the economy through innovation and entrepreneurship. Springerlink India, pp 585-598

Nutman PNS (1987) Communication skills for engineering students: an integrative approach. Eur J Eng Educ 12(4):367-375

Occupational English Test (OET) (2016) OET preparation support pack. https://www. occupationalenglishtest.org/resources/uploads/2015/08/OET-PreparationSupport-Pack-180515.pdf?x59645. Accessed 15 Sept 2017

Osman MM, Bachok S, Muslim SA, Bakri NIM (2015) Unemployment issues and problems in Kinta, Manjung and Kuala Kangsar, Perak, Malaysia. ProcediaSoc Behav Sci 168(9):389-399

Oxtoby R (1997) Barriers to the provision of cost-effective technical education in Bangladesh. Int J Educ Dev 17:91-99

Rahman AB, Hanafi NM, Mukhtar MI, Ahmad J (2014) Assessment practices for competency based education and training in vocational college, Malaysia. Procedia-Soc Behav Sci 112:1070-1076

Ramayah T, Cheah J, Chuah F, Ting H, Memon MA (2018) Partial least squares structural equation modeling (PLS-SEM) using SmartPLS 3.0: an updated and practical guide to statistical analysis, 2nd edn. Pearson Malaysia Sdn. Bhd., Kuala Lumpur

Rasul MS, Rauf RAA, Mansor AN, Yasin RM, Mahamod Z (2013) Graduate employability for manufacturing industry. Procedia-Soc Behav Sci 102:242-250

Reaves L (2004) Technical communication instruction in engineering schools a survey of top-ranked U.S. and Canadian programs. J Bus Tech Commun 18(4):452-490

Ross A (2000) Curriculum construction and critique. Falmer Press, London

Rus D (2014) Technical communication as strategic communication characteristics of the English technical discourse. Procedia Technol 12:654-658

Shuib M (2005) Preparing graduates for employment. Bull Higher Educ Res 5:1-7

Singh P, Narasuman S, Thambusamy RX (2012) Refining teaching and assessment methods in fulfilling the needs of employment: a Malaysian perspective. Futures 44:136-147

Singh P, Thambusamy RX, Ramly MA (2014) Fit or unfit? perspectives of employers and university instructors of graduates' generic skills. ProcediaSoc Behav Sci 123:315-324

Strevens P (1988) ESP after twenty years: a re-appraisal. In: Tickoo M (ed) ESP: state of the art. SEAMEO Regional Language Centre, Singapore, pp 1-13

Tabbron G, Yang J (1997) The interaction between technical and vocational education and training (TVET) and economic development in advanced countries. Int J Educ Dev 17(3):323-334

Tyler RW (1949) Basic principles of curriculum and instruction. University of Chicago Press, Chicago

UNESCO (2011) Policy brief: ICTs in TVET. http://iite.unesco.org/pics/ publications/en/files/3214697.pdf. Accessed 7 Feb 2018.

Wellington J (1993) The work related curriculum: challenging the vocational imperatives. Kogan Page Limited, London

Yoo H, Manna VF (2015) Measuring English language workplace proficiency across subgroups: using CFA models to validate test score interpretation. Language Test 34:101-126

Yunos JM, Ahmad WMRW, Kaprawi N, Razally W (2006) System of technical \& vocational education \& training in Malaysia (TVET). Paper presented at the 2nd International TT-TVET EU-Asia-Link Project Meeting, VEDC Malang

Zaharim A, Ahmad I, Yusoff YM, Omar MZ, Basri H (2012) Evaluating the soft skills performed by applicants of Malaysian engineers. Procedia-Soc Behav Sci 60:522-528

Zhao X, Lynch JG, Chen Q (2010) Reconsidering Baron and Kenny: myths and truths about mediation analysis. J Consum Res 37:197-206

\section{Competing interests}

The authors declare no competing interests.

\section{Additional information}

Correspondence and requests for materials should be addressed to N.A.

Reprints and permission information is available at http://www.nature.com/reprints

Publisher's note Springer Nature remains neutral with regard to jurisdictional claims in published maps and institutional affiliations. 
(c) (i) Open Access This article is licensed under a Creative Commons Attribution 4.0 International License, which permits use, sharing, adaptation, distribution and reproduction in any medium or format, as long as you give appropriate credit to the original author(s) and the source, provide a link to the Creative Commons license, and indicate if changes were made. The images or other third party material in this article are included in the article's Creative Commons license, unless indicated otherwise in a credit line to the material. If material is not included in the article's Creative Commons license and your intended use is not permitted by statutory regulation or exceeds the permitted use, you will need to obtain permission directly from the copyright holder. To view a copy of this license, visit http://creativecommons.org/ licenses/by/4.0/.

(C) The Author(s) 2020 